\title{
Salinger's Depiction of Trauma in The Catcher in the Rye
}

\author{
Wan Roselezam Wan Yahya \\ Faculty of Modern Languages and Communication, University Putra Malaysia, Malaysia \\ Ruzbeh Babaee \\ Faculty of Modern Languages and Communication, University Putra Malaysia, Malaysia
}

\begin{abstract}
Although J. D. Salinger's The Catcher in the Rye (1951) is one of the most widely read novels in American literature, it has usually been prohibited in academic centers across the US from its publication. While many things were taboo and banned in 1950s America, Salinger talks about them frankly through his novel. From the time of its first publication, The Catcher has been seen as a depiction of trauma for many adolescents and young readers who have observed themselves opposed to the values of America. Salinger pursues a style of romantic individualism and sees society as innately corrupt. As a "trauma fiction," The Catcher exhibits the author's tormented relation to the war. The present study explores the root of trauma through the protagonist of the novel.
\end{abstract}

Index Terms - trauma, war, sex, 1950s America

\section{INTRODUCTION}

The Catcher in the Rye begins with the sixteen years old Holden Caulfield's despair departure from what might be the last in a series of schools that fail to nurture, inspire and support him, persuaded via a troublesome odyssey in New York. The story is written from the advantage of an "adult" who wants to relive that earlier time through his following life time and criticizes himself for contentment and not knowing better. It seems to be wrong to see the fiction as solely an attempt to recapture a lost past. It seems also to be incorrect to discuss that the novel is simply about issues of generational differences. But, it seems to be more about what "adulthood" regards cultural and political role in a traumatized society for which adults feel responsible.

It is also important to understand The Catcher in the Rye's popularity in relation to the history of the 1950s. Currently, critics have reconsidered the features of the 1950s as an era of optimism, uniformity, and harmony, referring to unspoken classifications, festering clashes, and hidden kinds of dissatisfaction and revolution. When many World War II soldiers happily rejoined American society, many others were suffering from psychic pain. Mental health centers developed during this era for increasing psychological complaints among soldiers and even common people. Millions of people, according to Alfred Kinsey, secretly were involved in different sexual affairs. Thus, if the Cold War raised patriotic feeling, the danger of universal destruction sustained scattered trauma, and the postwar era observed the emergence of pacifist group obligated to civil insubordination. As many Americans were not engaged in political activity during this era, for those who were dissatisfied with their lifestyles, for those who were in conflict with the American values, Holden was a misfit protagonist.

The economy of postwar was coming, and many American citizens could buy houses in the new areas. Many American people observed the necessity of defending the US and the freedom that it allegedly protected against the communist danger. In that era, however, thinkers considered patterns of popular conformity. Mass products, system of bureaucracy, and same designed suburbs, they feared, served to homogenize the people, and created what David Riesman (1950) observes as "the other-directed" human being, or what William Whyte (1956) calls the "organization man". Holden represents his individual term of disparagement, "phony," and so wants to share trauma of a conformist culture. Indeed, Holden becomes a representative of a generation who observed the destruction and experienced the trauma of the war. Similarly, many other writers after Salinger depicted the trauma and destruction of WWII. For instance, Kurt Vonnegut in Slaughterhouse-Five (1969) illustrates Billy, like a counterpart for Holden, Salinger, and Vonnegut himself, who experienced "birth and death many times" (Babaee, WanYahya \& Sivagurunathan 2014, p. 240) and accepted "war and [its] destruction" (Babaee, Wan Yahya \& Sivagurunathan 2014, p. 241). The present study traces the root of this trauma through a figure like Holden whose story is truly a reflection of a generation of fear, anxiety, and depression.

\section{SALINGER's Personal EXPERIENCE of TRAuma}

Any assessment on Salinger's success should consider the merit of his works. Like Ginsberg, Kerouac, and Burroughs, Salinger has been known as an influential literary figure. A keen advocator of American entry into the war, 
Salinger tried to enlist in mid-1941 prior to America was officially in war, but his views toward the war as well as his reflection would have been typical of the era. (Hamilton, 1998, p. 69) Salinger was writing in the war. From 1940 to 1945, he published twenty-two works that half of them have war-related theme, mainly praising wartime heroism. As in 'The Last Day of the Last Furlough', the hero expresses his yearning for defending the country against invaders: "I believe in this war [. . . I believe in killing Nazis and Fascists and Japs because there's no other way that I know of" (A.P. Salinger, 1944, p. 10).

According to Alexander Salinger, the war changed Salinger's "patriotic, almost romantic view of war and the military forever" (100). According to Salinger's daughter:

While the war was often in the foreground of our family life, it was always in the background. It was the point of reference that defined everything else in relation to it. [. . .] As long as I've known him, my father has never taken being warm and dry and not being shot at for granted. [. . .] The constant presence of the war, as something not really over, pervaded the years I lived at home (M. P. Salinger, 2001, p.44).

In fact, there was something more important than the loss of 'romantic' illusion. Salinger represents what transpired in the mind of his war soldiers in his post-war fiction. Salinger's life is labeled a personal experience of trauma of the Cold War. According to Felman and Laub (1992), the Second World War was the "watershed trauma of our times - not an event encapsulated in the past, but as a history which is essentially not over, a history whose repercussions are omnipresent" (p. xiv).

The Catcher is a reflection of Salinger's personal experience of war and trauma, and Holden is modeled based on his youth and the novel can be read as his biography. In a 1954 interview, Salinger noted "My boyhood was very much the same as that of the boy in the book [Catcher]" (Salinger, 1999, p.177-8).

\section{TRAUMA}

By the events such as the Holocaust and the atomic bombings of Hiroshima, trauma became, according to Granofsky (1995), the experience of the second half of the twentieth century - and "the shock at the destructive potential in human depravity given free rein by technology inconceivable before 1945" leads to the "trauma novel" (p. 11).

Although philosophers totally agree on the factors leading to trauma - "a psychologically distressing event outside the range of usual human experience generating intense fear, terror, and helplessness" - also they emphasize the complicate reflections on the part of victim trying to grip traumatic shock (Granofsky, 1995, p. 16).

According to Kali Tal (1996), the subject has to "tell and retell the story of the traumatic experience, to make it "real" both to the victim and to the community" (p. 21). Also philosophers have considered how, under the influence of trauma, memories and perceptions have become suspended: "No trace of a registration of any kind is left in the psyche, instead, a void, a hole is found" (Caruth, 1995, p. 6).

Whitehead (2004) considers, in a relevant comment to Salinger, how the trauma becomes "not fully acknowledged at the time it occurs [...] and only becomes an event at some later point" (p. 6). But as proposing that a range of dysfunctional manners might be observed in trauma victims, philosophers have also considered approaches through which victims try to grip its impacts. Itzvan Deak (1997) sees trauma victims try to retreat into "idyllic memories of a mythicized past" (p. 38).

Granofsky (1995) observes a "fragmentation" of self that yields to a stage of "regression" that is able to mark a primary step toward getting back to 'normal' life, and a progress that can reinforce the trauma victim's emotions of loneliness and vulnerability (Granofsky, 1995, p. 18). Salinger's post-war work fit into the pattern of regression. Salinger's The Catcher, depicts such condition. Considering any parallels between Salinger's life and the protagonist of his novel, it can be claimed that Holden is "a character whose curriculum vitae is in almost every detail like the author's own" (Hamilton, 1998, p. 12).

\section{HOLDEN'S WORLD}

The Catcher has been usually prohibited in academic centers across the US from its publication. While many things were taboo and banned, Salinger talks about them frankly through Holden. He explains the sexual affairs of his classmates, and his clumsy encounter with a prostitute. He states, “Sex is something I just don't understand. I swear to God I don't" (p. 54). Also, Holden argues his attempts with mental disorder, "I'll just tell you about this madman stuff that happened to me around last Christmas just before I got pretty run-down and had to come out here and take it easy" (p. 59). Holden reveals that besides his neurotic parents and an unfriendly atmosphere, social hierarchy, strict teachers, and a city of prostitutes takes part in his failure. Holden suggests a critical image of postwar America in conflict with basic norms, addressing himself "sort of an atheist" and "a pacifist." Holden states, "I'm sort of glad they've got the atomic bomb invented. If there's ever another war, I'm going to sit right the hell on top of it" (p. 127)—a statement aligning the US' military policies with the suicidal motivations of a bewildered adolescent.

Holden tries to resist the force of growing up and imagine adults' responsibilities against his own values. Not able to speculate on a single vocation which he would like to get into, Holden states in response to his sister Phoebe's recommendation that he becomes a lawyer: 
I mean they're all right if they go around saving innocent guys' lives all the time, and like that, but you don't do that kind of stuff if you're a lawyer. All you do is make a lot of dough and play golf and play bridge and buy cars and drink Martinis and look like a hot-shot. And besides. Even if you did go around saving guys' lives and all, how would you know if you did it because you really wanted to save guys' lives, or because you did it because what you really wanted to do was be a terrific lawyer, with everybody slapping you on the back and congratulating you in court when the goddam trial was over, the reporters and everybody, the way it is in the dirty movies? How would you know you weren't being a phony? The trouble is, you wouldn't (p. 72).

The laws, norms, and traditions in adults' vocation are so crafty, as Holden observes, adults thwart even the capacity to know one's hypocrisy or to recognize honesty from self-deception. Declining the legal vocation, Holden explains his desired profession in the most well-known lines of the text:

I keep picturing all these little kids playing some game in this big field of rye and all. Thousands of little kids, and nobody's around - nobody big, I mean-except me. And I'm standing on the edge of some crazy cliff. What I have to do, I have to catch everybody if they start to go over the cliff-I mean if they're running and they don't look where they're going I have to come out from somewhere and catch them. That's all I'd do all day. I'd just be the catcher in the rye and all. I know it's crazy, but that's the only thing I'd really like to be (p. 78).

Holden's desire to protect children from threats and let them enjoy their life as they wish shows his desire for suspending time, for inhabiting a space of young people conserved endlessly.

\section{HOLDEN’S TRAUMA}

Regarding the setting and Holden's age, social background and experience, the story considers what could be a "simpler", pre-trauma stage of life. Thus, as a "trauma fiction," The Catcher exhibits the author's tormented relation to the war. Whitehead (2004) states that "trauma does not lie in the possession of the individual to be recorded at will, but rather acts as a haunting or possessive influence which insistently and intrusively returns" (p. 6). As Holden shows an especial affability, also he finally addresses the entire of the society to consider some unknown hurt. Observing "the unbearable ordeal of having to endure, absorb, to take in with no end and no limit", Felman (1992) considers trauma as "unerasable and untranscendable" (p. 35-6).

Unable to forget, the victim sees the experience itself inexpressible - a side of trauma signified in Holden's story through the lack of clear references to the war - and the post-traumatic subjects come to observe the world through the lens of the trauma-inducing and reality-transforming events. Therefore, if The Catcher exemplifies the traumatized victim's return to the pre-trauma, that time is represented as everything except idyllic. Indeed, Holden stays in a numb state, close to suicidal depression. Seen as an example of the post-war adolescent's "spiritual odyssey", a teenager's pursuit of identity or the ambiguities in youth in the Cold War time, The Catcher shows the situations of injury, madness, illness, and suicide (an American coming-of-age story) (Steinle, 1991, p.128).

Holden is depicted as an isolated person who is obsessed with ideas of death and suicide, fraught with fear of disease and palsy, the roots of which can be seen in Holden's sadness over the death of Allie, his younger brother. In fact, Holden lives in a condition close to inconsolable mourning. Holden gets even more sternly persuaded of his forthcoming death, an instance of what Felman (1992) refers to as he talks of the trauma victim who fears "that fate will strike again" (p. 67).

Engaged in memories of Allie, lonely in his room, "so lonesome [... I almost wished I was dead" (p. 42), Holden sees himself in a Manhattan hotel room alone and overwhelmed in thought of "jumping out the window" (p. 94). He is persuaded that, similar to Allie, he suffers from a deadly disease: "a tumor on the brain" (p. 51); "pneumonia" (p. 139); "cancer" that would lead to his death "in a couple of months" (p. 176). Attacked by Maurice, Holden lies on the floor and states "I was dying [...] I was drowning" (p. 93). Also, Holden makes an image of himself with a "bullet in [his] guts" (p. 135). In another point, walking about the city, Holden is affected by fear of instant extinction: a "feeling that I'd never get to the other side of the street" (p. 178). According to Felman (1992), trauma is the feeling that "one is impotent to act" (p. 35). Holden feels powerless to influence the conditions: "I thought I'd just go down, [...] and nobody'd ever see me again" (p. 178).

Clearly, Holden's identification with his dead brother sustains the story's deeper flow. Memories of Allie repeat throughout the story, lending structure to Holden's story while representing the inescapable essence of his trauma. Obviously, any of those people that he sees on his travel around Manhattan cannot create the feeling of closeness that he has with his brother and every flaw he faces which confirms that loss of Allie is very influential in Holden's life. If the importance of Allie's loss is obvious enough, it can also be seen as a projection of what in the subject is "killed off". Allie, as a brother, embodies a death that Holden is experiencing as his own. In a turning point, sitting lonely at night in Central Park, Holden has a vision of himself joining to his dead brother. Hopelessly, he presents the funereal: "I felt sorry as hell for my mother and father. Especially my mother, because she still isn't over my brother Allie yet", and continues, "I hope to hell when I do die somebody has sense enough to just dump me in the river" (p. 139-40). Declining to have funeral ceremony only confirms his state of despair and weakness. In a post-mortem imagination of himself, Holden resumes "how old Phoebe would feel if I [. . .] died" (p. 140).

In order to get back to his normal life, Holden would like to have communication with people. An obsessive telephone user constantly calls to arrange date and make appointment; then, Holden experiences an urgent necessity to 
talk. He is striking up the conversation with everybody who wants to listen -classmates' parents, priests, cap drivers, visitors from Seattle- and takes a particular grudge against the people who reject to reply. Indeed, lack of answer is a main fact through which he evaluates other people: "That's the way you can always tell a moron. They never want to discuss anything" (p. 39). Although proud of some moral values, Holden chooses girls he sees by chance; makes date with his friends' girlfriend; and has a prostitute sent to his hotel room. But even such affairs end in miscommunication and isolation. As lack communication becomes more obvious, there takes place what Krystal (1995), about trauma victim, observes as a "destruction of basic trust", that is in others as well as oneself (p. 80)

In a story noticeably shows the reasons of Holden's situation, it is his confirmation of his brother's comment about the American army that an "Army practically as full of bastards as the Nazis were", and perception of the disaster of the atomic bomb that makes him more angry because "you got to hate everybody in the world" (p. 126-128). In the story when one hears an authorial self suffering the brutalizing impact of war, Holden states: "If there's another war, they better just take me out and stick me in front of a firing squad" (p. 127). Also, when his feelings of rage, depression and annihilation assemble, Holden says: "I'm going to sit right the hell on top of [the atomic bomb]" (p. 127). Indeed, In the allusion to atomic bomb, suicide, and mass destruction, we feel not only seemingly directed anger, but also a redirection of aggression into the self. While the story considers a society radically involved in a conflict with what is seen about the author's uneventful years, it is exactly such "uneventfulness" which makes the more irritation that the author is in its quest. A victim who finds himself as "perpetrator" of his victimization, Salinger perceives himself as yielded to an ideological system involved in the creating of a world of unbelievable horror and trauma.

\section{CONCLUSION}

Seen as an example of trauma fiction- both in its expression of impacts particular to trauma and its silence in revealing the sources of such impacts- The Catcher illustrates the maneuvering by which the authorial self manifested in Holden sought to work through his tormented relationship to the war and its trauma.

\section{REFERENCES}

[1] Caruth, C. (1995) Trauma: Explorations in Memory. Baltimore, Md.: Johns Hopkins University Press.

[2] Babaee, R., Wan Yahya, W. R., \& Sivagurunathan, S. (2014). Dystopian Cybernetic Environment in Kurt Vonnegut's Slaughterhouse-Five. Theory and Practice in Language Studies, 4(2), 237-243.

[3] Deak, I. (1997). Memories of Hell. The New York Review of Books.

[4] Felman S. and Laub D. (1992).Testimony: Crises of Witnessing in Literature, Psychoanalysis, and History. New York and London: Rutledge.

[5] Granofsky, R. (1995). The Trauma Novel. New York: Peter Lang.

[6] Hamilton, I. (1998). In Search of J. D. Salinger. London: Bloomsbury

[7] Kinsey, A. (1953). Sexual Behavior in the Human Female. Philadelphia: Saunders.

[8] Krystal, H. (1995). 'Trauma and Aging: A Thirty-Year Follow-Up,' in Caruth, Trauma. Johns Hopkins University Press.

[9] Riesman, D. (1950). The Lonely Crowd: A Study of the Changing American Character. New Haven: Yale University Press.

[10] Salinger, J. D. (1951). The Catcher in the Rye. Boston: Little, Brown Publisher.

[11] Salinger, J. D. (1944).“The Last Day of the Last Furlough". The Saturday Evening Post.

[12] Salinger, M. A. (2001). Dream Catcher: A Memoir. London: Scribner/Simon \& Schuster.

[13] Salinger, P. A. (1999). A Biography. Los Angeles, Calif.: Renaissance Books.

[14] Steinle, P. (1991). "If a Body Catch a Body": The Catcher in the Rye Censorship Debate as Expression of Nuclear Culture', in R. Edsforth and L. Bennett (eds). Popular Culture and Political Change in Modern America, Albany, NY: State University of New York Press.

[15] Tal, K. (1996). Worlds of Hurt: Reading the Literature of Trauma. Cambridge: Cambridge University Press.

[16] Whitehead, A. (2004). "Trauma Fiction". Edinburgh: Edinburgh University Press.

[17] Whyte, W. (1956). The Organization Man. New York: Simon \& Schuster.

Wan Roselezam Wan Yahya is Associate Professor of English Literature in the Department of English, Faculty of Modern Languages \& Communication, Universiti Putra Malaysia. Her research interests, like her teaching, span several areas within En glish literature, World literatures in English, and literature in the ESL contexts. Much of her research and publications focuses on gender, cultural identity, and the teaching and learning of literature in the second language. She is also interested in reading lite rature through existential and absurdist philosophy as well as through eco-critical lens. She continues to be interested in various aspects of literatures written in English, particularly but not exclusively that of the eighteenth and nineteenth-century. A further and ongoing interest of hers is dystopian literature and literature of the grotesque.

Ruzbeh Babaee is a researcher of English literature in the Faculty of Modern Languages and Communication, Universiti Putra Malaysia. His areas of research are postmodern fiction, dystopian fiction, media and cultural studies. 